\title{
TINGKAT PENGETAHUAN ANAK TENTANG PEMELIHARAAN KEBERSIHAN GIGI DAN MULUT TERHADAP OHI-S DAN TERJADINYA KARIES PADA SISWA/I KELAS IV SDN 101740 TANJUNG SELAMAT KECAMATAN SUNGGAL TAHUN 2014
}

\author{
Sri Junita Nainggolan \\ Jurusan Keperawatan Gigi Politeknik Kesehatan Kemenkes Medan
}

\begin{abstract}
Abstrak
Pemeliharaan kebersihan gigi dan mulut merupakan upaya untuk mempertahankan kesehatan gigi dan mulut yang bertujuan untuk meningkatkan kesadaran sikap dan perilaku seseorang dalam kemampuan pemeliharan dibidang kesehatan gigi dan mulut. apabila kebersihan gigi dan mulut diabaikan dapat menyebabkan kerusakan jaringan gigi dan penyangga gigi. Penelitian ini dilakukan secara deskriptif dengan metode survey yang bertujuan untuk mengetahui tingkat pengetahuan anak tentang pemeliharaan kebersihan gigi dan mulut terhadap OHI-S dan terjadinya karies pada siswa/i kelas IV SDN 101740 Tanjung Selamat Kecamatan Sunggal Tahun 2014. Populasi berjumlah 30 siswa/i dan sampel adalah total populasi yang diperiksa. Dari hasil penelitian diperoleh data sebagai berikut, tingkat pengetahuan tentang menyikat gigi memiliki kriteria pengetahuan baik sebanyak 19 siswa $(63,33 \%)$. Tingkat pengetahuan tentang diet makanan, ditemukan kriteria pengetahuan baik sebanyak 27 siswa (90\%). Untuk tingkat pengetahuan tentang alat bantu dalam pembersihan gigi hanya 4 siswa $(13,33 \%)$ yang memiliki kriteria baik. Debris indeks rata-rata sedang $(1,536)$, kalkulus indeks rata-rata baik $(0,513)$, OHI-S rata-rata sedang $(2,049)$ dan 26 siswa yang terkena karies $(86,667 \%)$.Diharapkan peran orang tua dalam mendidik anak untuk menjaga kebersihan gigi dan mulut agar terhindar dari penyakit gigi dan mulut.
\end{abstract}

Kata Kunci : Pengetahuan anak, OHI-S, karies

\section{Pendahuluan}

Kesehatan merupakan salah satu penunjang aktivitas manusia. Tanpa adanya kesehatan manusia tidak dapat melaksanakan aktivitasnya dengan baik, apabila kesehatannya terganggu. Dalam UU RI No 36 tahun 2009 BAB 1 pasal 1 ayat 1 kesehatan adalah keadaan sehat baik secara fisik, mental, spiritual, maupun sosial yang memungkinkan setiap orang untuk hidup produktif secara sosial dan ekonomis.

Dalam UU Kesehatan tahun 2009 BAB VI pasal 93 tentang kesehatan gigi dan mulut. Adapun pasal 93 berisikan bahwa pelayanan kesehatan gigi dan mulut dilakukan untuk memelihara dan meningkatkan derajat kesehatan masyarakat dalam bentuk peningkatan kesehatan gigi, pencegahan penyakit gigi, pengobatan penyakit gigi, dan pemulihan kesehatan gigi oleh pemerintah, pemerintah daerah atau masyarakat yang dilakukan secara terpadu, terintegrasi, dan berkesinambungan.

Menurut Survei Kesehatan Rumah Tangga (SKRT) dan survei yang dilakukan Departemen Kesehatan RI tahun 2007 menunjukan bahwa secara umum, prevalensi penyakit gigi dan mulut tertinggi meliputi $72,1 \%$ penduduk, $46,6 \%$ diantaranya karies aktif. Angka itu bukan merupakan angka yang dapat diabaikan karena telah terbukti bahwa penyakit gigi dan mulut dapat mempengaruhi produktivitas masyarakat.

Pembangunan dibidang kesehatan gigi dan mulut merupakan salah satu bagian dari pembangunan kesehatan secara menyeluruh yang mempunyai tanggung jawab besar terhadap peningkatan nilai derajat kesehatan gigi dan mulut di masyarakat. Upaya kesehatan gigi perlu ditinjau dari aspek lingkungan, pendidikan, kesadaran masyarakat dan penanganan kesehatan gigi termasuk pencegahan dan perawatan. Untuk mendapatkan hasil yang baik, dalam upaya kesehatan gigi perlu diketahui masalah yang berkaitan dengan proses terjadinya kerusakan gigi (Ismu Suharsono Suwelo,1992).

Kesehatan gigi dan mulut merupakan bagian dari kesehatan tubuh yang tidak dapat dipisahkan satu dengan yang lainnya, karena akan mempengaruhi kesehatan tubuh secara keseluruhan. Gigi merupakan salah satu bagian tubuh yang memiliki fungsi. Secara umum fungsi gigi sebagai berikut pertama membantu fungsi bicara, membentuk wajah, membantu proses penyaringan makanan yang masuk ke dalam rongga pencernaan dan alat untuk mengunyah sehingga makanan dapat mudah untuk ditelan dan masuk ke dalam rongga pencernaan berikutnya (Srigupta,2004).

Banyak orang tidak mengetahui bahwa gigi dan mulut yang tidak sehat dapat menimbulkan penyakit lain. Hal itu terlihat karena kurangnya tingkat pengetahuan dan kesadaran masyarakat tentang pentingnya kebersihan gigi dan mulut terhadap terjadinya karies. Pengetahuan adalah sebuah hasil yang tidak tahu menjadi tahu, ini terjadi setelah orang melakukan penginderaan terhadap suatu objek tertentu. Penginderaan terjadi melalui panca indra 
manusia, yaitu indra penglihatan, pendengaran, penciuman, rasa dan raba. Sebagian besar pengetahuan manusia diperoleh dari mata dan telinga.

Menjaga kebersihan gigi dan mulut merupakan upaya untuk mempertahankan kesehatan gigi dan mulut yang dilakukan seseorang. Tujuan kesehatan gigi dan mulut meningkatkan kesadaran sikap dan perilaku seseorang dalam kemampuan memelihara dibidang kesehatan gigi dan mulut dan mampu melakukan pengobatan sedini mungkin dengan cara memberikan pengertian kepada seseorang atau masyarakat tentang pentingnya pemeliharaan kebersihan gigi dan mulut terhadap status kebersihan gigi dan mulut dan terjadinya karies.

Kebersihan gigi dan mulut bertujuan untuk menghindari terbentuknya plak, yang mempunyai kecenderungan untuk tinggal di dalam rongga mulut dan melekat pada gigi, bila dibiarkan atau tidak dijaga kebersihannya dapat menyebabkan kerusakan gigi misalnya timbulnya lubang pada gigi atau karies dan kerusakan jaringan pendukungnya. Untuk dapat menilai kebersihan gigi dan mulut secara objektif digunakan suatu indeks skor. Indeks adalah angka yang menyatakan keadaan klinis yang didapat pada waktu dilakukan pemeriksaan. Suatu indeks yang digunakan adalah OHI-S yang menggambarkan keadaan kebersihan gigi dan mulut dari responden yang dinilai dari debris atau sisa makanan dan kalkulus atau karang gigi yang terdapat pada permukaan gigi dengan menggunakan Oral Hygiene Index Simplified oleh Green dan Vermilion. Cara penilaian OHI$\mathrm{S}$ adalah dengan menjumlahkan skor Debris Indeks (DI) dan Calculus Indeks (CI).

Karies merupakan suatu penyakit pada jaringan keras gigi yaitu email, dentin dan sementum disebabkan aktivitas jasad renik yang ada dalam suatu karbohidrat yang diragikan. Proses karies ditandai dengan terjadinya demineralisai pada jaringan keras gigi, diikuti dengan bahan organiknya. Hal ini akan meyebabkan terjadinya infasi bakteri dan kerusakan pada jaringan pulpa serta penyebaran infeksi kejaringan periapikal dan menimbulkan rasa nyeri. Karies gigi inilah yang apabila tidak dirawat dan dicegah dengan baik dan benar, akhirnya dapat menyebabkan kerusakan pada jaringan penyangga gigi sehingga dapat mengakibatkan menurunnya angka derajat kesehatan gigi dan mulut di masyarakat (Sondang Pintauli, 2008).

Untuk mencegah terjadinya karies gigi dibutuhkan pemeliharaan kesehatan gigi dan mulut yang optimal. Salah satu cara yang dapat dilakukan untuk mencegah terjadinya gigi berlubang yaitu dengan cara menyikat gigi yang baik dan benar. Masa sekolah dasar antara usia (6-12 tahun) merupakan masa periode usia yang penting bagi perkembangan manusia yang akan datang. Karena anak sekolah dasar merupakan salah satu kelompok yang rentan terhadap penyakit gigi dan mulut seperti masalah gigi berlubang, masalah bau mulut dan masalah pola makan yang baik yang dapat mempengaruhi kesehatan gigi dan mulut.

Berdasarkan uraian di atas penulis tertarik untuk melakukan penelitian di SDN 101740 Tanjung Selamat
Kecamatan Sunggal tahun 2014, untuk mengetahui bagaimana Tingkat Pengetahuan Anak Tentang Pemeliharaan Kebersihan Gigi dan Mulut Terhadap OHI-S dan Terjadinya Karies Pada Siswa/i Kelas IV SDN 101740 Tanjung Selamat Kecamatan Sunggal.

\section{Tujuan Penelitian}

Penelitian ini bertujuan untuk mengetahui tingkat pengetahuan anak tentang pemeliharaan kebersihan gigi dan mulut tehadap OHI-S dan terjadinya karies pada siswa/i kelas IV di SDN 101740 Tanjung Selamat Kecamatan Sunggal.

\section{Manfaat Penelitian}

1. Untuk memberikan wawasan dan pengetahuan bagi siswa/i SDN 101740 Tanjung Selamat Kecamatan Sunggal dalam pemeliharaan kebersihan gigi dan mulut terhadap OHI-S dan terjadinya karies.

2. Sebagai bahan masukan dan informasi bagi pihak sekolah, seberapa besar pengetahuan anak tentang karies gigi kelas IV SDN 101740 Desa Tanjung Selamat Kecamatan Sunggal.

3. Sebagai masukan bagi peneliti lain dan sebagai bahan referensi di perpustakaan Jurusan Keperawatan Gigi Politeknik Kesehatan Medan.

\section{Jenis Dan Desain Penelitian}

Jenis penelitian yang dilakukan adalah penelitian deskriptif dengan metode survey dimana penelitian ini bertujuan untuk mengetahui gambaran mengenai tingkat pengetahuan anak tentang pemeliharaan kebersihan gigi dan mulut terhadap OHI-S dan terjadinya karies pada siswa/i kelas IV di SDN 101740 Tanjung Selamat

\section{Populasi Dan Sampel Penelitian}

Populasi adalah keseluruhan objek penelitian atau objek yang diteliti. Populasi dari penelitian adalah siswa/i kelas IV SDN 101740 Tanjung Selamat Kecamatan Sunggal tahun 2014

Sampel adalah objek yang akan diteliti dan dianggap mewakili seluruh populasi (Notoatmojo, 2010). Dalam pengambilan sampel pada penelitian ini mengarah pada pendapat Suharsimi Arikunto yang menyatakan bahwa apabila subjek penelitian kurang dari 100, maka lebih baik diambil semua. Tetapi jika jumlahnya lebih dari 100 dapat diambil $10-15 \%$ atau 20-25\% atau lebih. Sampel diambil semua karena jumlahnya kurang dari 100 yaitu berjumlah 30 orang.

\section{Hasil Penelitian}

Data yang dikumpulkan adalah hasil dari penelitian yang dilakukan pada 30 siswa di SDN 101740 Tanjung Selamat Kecamatan Sunggal tahun 2014. Pengumpulan data dilakukan dengan pemberian kuesioner dan pemeriksaan langsung. Setelah data terkumpul analisa data dilakukan dengan membuat tabel distribusi frekuensi. 
Tabel 1. Distribusi Frekuensi Tingkat Pengetahuan Anak Tentang Menyikat Gigi Pada Siswa/i Kelas IV Terhadap OHI-S dan Terjadinya Karies di SDN 101740 Tanjung Selamat Kecamatan Sunggal Tahun 2014

\begin{tabular}{clcc}
\hline No. & Kriteria & sampel (n) & $\begin{array}{c}\text { Persentase } \\
(\%)\end{array}$ \\
\hline 1. & Baik & 19 & $63,33 \%$ \\
2. & Sedang & 9 & $30 \%$ \\
3. & Buruk & 2 & $6,67 \%$ \\
\hline & Jumlah & 30 & $100 \%$ \\
\hline
\end{tabular}

Berdasarkan tabel di atas dapat dilihat bahwa tingkat pengetahuan tentang menyikat gigi dari 30 orang siswa, 19 siswa $(63,33 \%)$ memiliki tingkat pengetahuan baik, 9 siswa (30\%) memiliki tingkat pengetahuan sedang dan 2 siswa $(6,67 \%)$ memiliki tingkat pengetahuan buruk.

Tabel 2. Distribusi Frekuensi Tingkat Pengetahuan Anak Tentang Diet Makanan Pada Siswa/i Kelas IV Terhadap OHI-S dan Terjadinya Karies di SDN 101740 Tanjung Selamat Kecamatan Sunggal Tahun 2014

\begin{tabular}{clcc} 
No. & Kriteria & sampel (n) & $\begin{array}{c}\text { Persentase } \\
(\%)\end{array}$ \\
\hline 1. & Baik & 27 & $90 \%$ \\
2. & Sedang & 3 & $10 \%$ \\
3. & Buruk & 0 & $0 \%$ \\
\hline & Jumlah & 30 & $100 \%$ \\
\hline
\end{tabular}

Berdasarkan tabel di atas dapat dilihat bahwa tingkat pengetahuan tentang diet makanan dari 30 orang siswa, 27 siswa (90\%) memiliki tingkat pengetahuan baik, 3 siswa (10\%) memiliki tingkat pengetahuan sedang dan tidak ada siswa yang memiliki tingkat pengetahuan buruk.

Tabel 3. Distribusi Frekuensi Tingkat Pengetahuan Anak Tentang Diet Makanan Pada Siswa/i Kelas IV Terhadap OHI-S dan Terjadinya Karies di SDN 101740 Tanjung Selamat Kecamatan Sunggal Tahun 2014

\begin{tabular}{clcc}
\hline No. & Kriteria & sampel (n) & Persentase (\%) \\
\hline 1. & Baik & 27 & $90 \%$ \\
2. & Sedang & 3 & $10 \%$ \\
3. & Buruk & 0 & $0 \%$ \\
\hline & Jumlah & 30 & $100 \%$ \\
\hline
\end{tabular}

Berdasarkan tabel di atas dapat dilihat bahwa tingkat pengetahuan tentang diet makanan dari 30 orang siswa, 27 siswa (90\%) memiliki tingkat pengetahuan baik, 3 siswa (10\%) memiliki tingkat pengetahuan sedang dan tidak ada siswa yang memiliki tingkat pengetahuan buruk.

Tabel 4. Debris Indeks Rata-rata Pada Siswa/i Kelas IV SDN 101740 Tanjung Selamat Kecamatan Sunggal Tahun 2014

\begin{tabular}{ccc}
\hline $\begin{array}{c}\text { Jumlah } \\
\text { Siswa }\end{array}$ & $\begin{array}{c}\text { Jumlah Debris } \\
\text { Indeks Total }\end{array}$ & $\begin{array}{c}\text { Debris Indeks } \\
\text { Rata-rata }\end{array}$ \\
\hline 30 & 46,08 & 1,536 \\
\hline
\end{tabular}

Berdasarkan tabel di atas dapat dilihat bahwa tingkat kebersihan gigi dan mulut (Debris Indeks Rata-rata) pada siswa/i kelas IV SDN 101740 Tanjung Selamat Kecamatan Sunggal tahun 2014 adalah sedang $(1,536)$.

Tabel 5. Kalkulus Indeks Rata-rata Pada Siswa/i Kelas IV SDN 101740 Tanjung Selamat Kecamatan Sunggal Tahun 2014

\begin{tabular}{ccc}
\hline $\begin{array}{c}\text { Jumlah } \\
\text { Siswa }\end{array}$ & $\begin{array}{c}\text { Jumlah Kalkulus } \\
\text { Indeks Total }\end{array}$ & $\begin{array}{c}\text { Kalkulus Indeks } \\
\text { Rata-rata }\end{array}$ \\
\hline 30 & 15,4 & 0,513 \\
\hline
\end{tabular}

Berdasarkan tabel di atas dapat dilihat bahwa tingkat kebersihan gigi dan mulut (Kalkulus Indeks Ratarata) pada siswa/i kelas IV SDN 101740 Tanjung Selamat Kecamatan Sunggal tahun 2014 adalah baik $(0,536)$.

Tabel 6. OHI-S Rata-rata Pada Siswa/i Kelas IV SDN 101740 Tanjung Selamat Kecamatan Sunggal Tahun 2014

\begin{tabular}{ccc}
\hline Jumlah Siswa & $\begin{array}{c}\text { Jumlah } \\
\text { Keseluruhan OHI-S }\end{array}$ & $\begin{array}{c}\text { OHI-S Rata- } \\
\text { rata }\end{array}$ \\
\hline 30 & 61,48 & 2,049 \\
\hline
\end{tabular}

Berdasarkan tabel di atas dapat dilihat bahwa OHI-S rata-rata adalah 2,049. Ini berarti tingkat kebersihan gigi dan mulut pada siswa/i kelas IV SDN 101740 Tanjung Selamat Kecamatan Sunggal tahun 2014 adalah kriteria sedang.

Tabel 7. Distribusi Persentase Siswa Yang terkena Karies dan Bebas Karies Pada Siswa/i Kelas IV SDN 101740 Tanjung Selamat Kecamatan Sunggal Tahun 2014

\begin{tabular}{llcc}
\hline No & Kriteria & sampel (n) & $\begin{array}{c}\text { Persentase } \\
(\%)\end{array}$ \\
\hline 1. & Ada Karies & 26 & $86,667 \%$ \\
2. & Tidak Ada Karies & 4 & $13,333 \%$ \\
\hline & Jumlah & 30 & $100 \%$ \\
\hline
\end{tabular}

Berdasarakan tabel di atas dapat dilihat bahwa dari 30 orang siswa terdapat 26 orang siswa yang terkena karies $(86,667 \%)$ sedangkan 4 orang siswa dinyatakan bebas karies $(13,333 \%)$.

\section{Pembahasan}

Berdasarkan tabel 1 di atas dapat dilihat bahwa tingkat pengetahuan tentang menyikat gigi dari 30 orang siswa, 19 orang siswa $(63,33 \%)$ memiliki tingkat pengetahuan yang baik, 9 orang siswa $(30 \%)$ memiliki tingkat pengetahuan sedang, dan 2 orang siswa $(6,67 \%)$ memiliki tingkat pengetahuan yang buruk.

Menurut Monang panjaitan (1995) mengatakan bahwa menyikat gigi itu sangat penting, karena menyikat gigi bertujuan untuk memelihara kebersihan dan kesehatan gigi dan mulut terutama gigi serta jaringan sekitarnya.

Berdasarkan tabel 2 dapat dilihat bahwa tingkat pengetahuan tentang diet makanan dari 30 orang siswa, 27 orang siswa $(90 \%)$ memiliki tingkat pengetahuan baik, 3 orang siwa (10\%) memiliki tingkat pengetahuan sedang 
dan tidak ada siswa yang memiliki tingkat pengetahuan buruk. Kontrol Plak juga dapat dilakukan dengan mengkonsumsi makanan berserat. Kebiasaan mengkonsumsi makan-makanan yang mengandung serat tidak merangsang pembentukan plak, melainkan berperan sebagai pengendali plak secara alamiah. Jenis makanan yang mengandung serat misalnya buah-buahan, sayuran hijau, kacang-kacangan dan serealia. Makanan berserat seperti sayur-sayuran dan buah-buahan mengandung 7595\% air. Sayuran dan buah-buahan berserat dan berair akan bersifat membersihkan karena harus dikunyah dan dapat merangsang sekresi saliva.

Berdasarkan tabel 3 dapat dilihat bahwa tingkat pengetahuan anak tentang alat bantu yang digunakan dalam pembersihan gigi dari 30 orang siswa, 4 orang siswa $(13,33 \%)$ memiliki tingkat pengetahuan baik, 22 orang siswa $(73,33 \%)$ memiliki tingkat pengetahuan sedang dan 4 orang siswa $(13,33 \%)$ memiliki tingkat pengetahuan buruk.

Sekalipun seseorang menyikat gigi dengan rajin dan dengan cara yang baik namun ada kalanya daerah interdental sering tidak dicapai oleh sikat gigi. Oleh karena itu plak di daerah interdental tidak dapat dibersihkan. Alat bantu dalam pembersihan gigi seperti benang gigi, tusuk, dan obat kumur yang mana dalam hal ini penggunaanya harus tepat dan benar dalam membersihkan bagian gigi yang tidak dapat dicapai dengan sikat gigi.

Berdasarkan tabel 4 dapat dilihat bahwa debris indeks rata-rata pada 30 orang siswa memiliki jumlah debris indeks total 46,08 dengan kriteria sedang 1,536. Debris yaitu sisa-sisa makanan yang tertinggal di dalam mulut, yang terdapat pada permukaan gigi, di antara gigi dan di bawah gingiva setelah seseorang makan. Pada umumnya debris mudah dibersihkan dengan cara gerakangerakan bibir, pipi, lidah dan juga berkumur. Kecepatan pembersihan debris dari rongga mulut bervariasi menurut jenis makanan dan individunya.

Dari tabel 5 dapat dilihat bahwa kalkulus indeks rata-rata pada 30 orang siswa yang memiliki jumlah kalkulus indeks total 15,4 dengan kriteria baik yaitu 0,513. Menurut Machfoedz (2008) apabila gigi jarang dibersihkan, maka lama-kelamaan sisa-sisa makanan serta bahan-bahan yang ada di dalam ludah akan bersatu menjadi keras dan melekat pada permukaan gigi. Biasanya dimulai dari daerah leher gigi. Lama kelamaan dapat menyelimuti permukaan mahkota gigi. Karang gigi berwarna kekuning-kuningan. Bila sampai di bawah gusi warnanya menjadi coklat sampai kehitam-hitaman.

Berdasarkan tabel 6 dapat dilihat bahwa OHI-S rata-rata pada 30 orang siswa memiliki dengan kriteria sedang yaitu 2,049. Menurut Monang Panjaitan (1995) kebersihan gigi dan mulut adalah pemeliharaan kebersihan rongga mulut dengan pembuangan plak, bakteri melalui penyikatan. Menjaga kebersihan gigi dan mulut merupakan upaya untuk mempertahankan kesehatan gigi dan mulut yang dilakukan seseorang. Salah satu upaya untuk memelihara kebersihan gigi dan mulut adalah dengan menyikat gigi. Selain dengan menyikat gigi ada kalanya daerah interdental sering tidak dapat disingkirkan oleh sikat gigi. Untuk dapat membersihkan daerah interdental diperlukan alat bantu dalam pembersihan gigi misalnya benang gigi dan tusuk gigi.

Berdasarkan tabel 7 dapat dilihat bahwa dari 30 orang siswa terdapat 26 orang siswa yang terkena karies $(86,667 \%)$ sedangkan 4 orang siswa dinyatakan bebas karies (13,333\%). Menurut Edwina A.M. Kidd (1992) karies gigi merupakan suatu penyakit pada jaringan keras gigi yaitu email, dentin dan sementum yang disebabkan aktivitas jasad renik yang ada dalam suatu karbohidrat yang diragikan.

\section{Simpulan}

Dari hasil penelitian tentang tingkat pengetahuan anak tentang pemeliharaan kebersihan gigi dan mulut terhadap OHI-S dan terjadinya karies yang dilakukan dapat disimpulkan bahwa pada siswa/i kelas IV SDN 101740 Tanjung Selamat Kecamatan Sunggal tahun 2014 dengan sampel 30 siswa adalah

1. Pengetahuan pemeliharaan kebersihan gigi dan mulut dengan:

Menyikat gigi

a. Kriteria baik dengan persentase $66,33 \%$

b. Kriteria sedang dengan persentase $30 \%$

c. Kriteria buruk dengan persentase $6,67 \%$

Diet Makanan

a. Kriteria baik dengan persentase $90 \%$

b. Kriteria sedang dengan persentase $10 \%$

c. Tidak ada siswa yang memperoleh kriteria buruk

Alat bantu yang digunakan dalam pembersihan gigi

a. Kriteria baik dengan persentase $13,33 \%$

b. Kriteria sedang dengan persentase $73,33 \%$

c. Kriteria buruk dengan persentase $13,33 \%$

2. Nilai Kebersihan Gigi dan Mulut

a. Debris Indeks Rata-rata adalah sedang $(1,536)$

b. Kalkulus Indeks Rata-rata adalah baik $(0,513)$

c. OHI-S Rata-rata adalah sedang $(2,049)$

3. Persentase siswa/i yang terkena karies adalah 26 siswa $(86,667 \%)$

4. Persentase siswa/i yang tidak terkena karies adalah 4 siswa $(13,333 \%)$

\section{Saran}

1. Diharapkan peran orang tua dalam mendidik anak dalam pemeliharaan gigi dan mulut dengan memperhatikan cara dan waktu menyikat gigi dengan cara yang baik dan tepat serta memperhatikan ketersediaan alat bantu dalam pembersihan gigi untuk mendapatkan kebersihan gigi dan mulut yang baik.

2. Diharapkan kepada pihak SDN 101740 Tanjung Selamat Kecamatan Sunggal mengembangkan kerja sama dengan Puskesmas setempat untuk kegiatan Usaha Kesehatan Gigi Sekolah agar diperoleh tingkat kebersihan gigi dan mulut yang lebih baik serta memperluas pengetahuan siswa/i mengenai pemeliharaan kebersihan gigi dan mulut.

3. Peningkatan motivasi pada siswa/i dan orang tua untuk melakukan perawatan kesehatan gigi dan mulut sedini mungkin memperhatikan kesehatan gigi dan 
mulut putra-putrinya serta memeriksakan gigi anakanaknya minimal 6 bulan sekali ke dokter gigi.

\section{Daftar Pustaka}

Arikunto, S., 2006. Prosedur Penelitian Suatu Pendekatan Praktis, Rineka Cipta,Jakarta.S.

Srigupta, Aziz Ahmad, 2004, Perawatan Gigi dan Mulut, Prestasi Pustaka. Jakarta.

Kidd, E. A. M. Bechal, S. J. 1991. Dasar-dasar Karies Dan Penanggulanganny. EGC. Jakarta.

Mahfoeds, I., 2008. Menjaga Kesehatan Gigi dan Mulut Anak-Anak dan Ibu Hamil. Fitramayana. Yogyakarta.
Notoatmodjo, S, 2010. Metodologi Penelitian Kesehatan. Rineka Cipta, Jakarta.

, 2010. Promosi Kesehatan Dan Ilmu Perilaku. Rineka Cipta, Jakarta.

Panjaitan, M, 1995. Ilmu Pencegahan Karies Gigi.Press USU

Pintauli, S, Taizo Hamada, 2010. Menjaga Gigi dan Mulut Sehat. USU PRESS

Tarigan R, 1995, Karies Gigi. EGC Jakarta

http://mydentistdiary.blogspot.com/2010/05/kariesmenurut-kedalamannya-dapat.html 